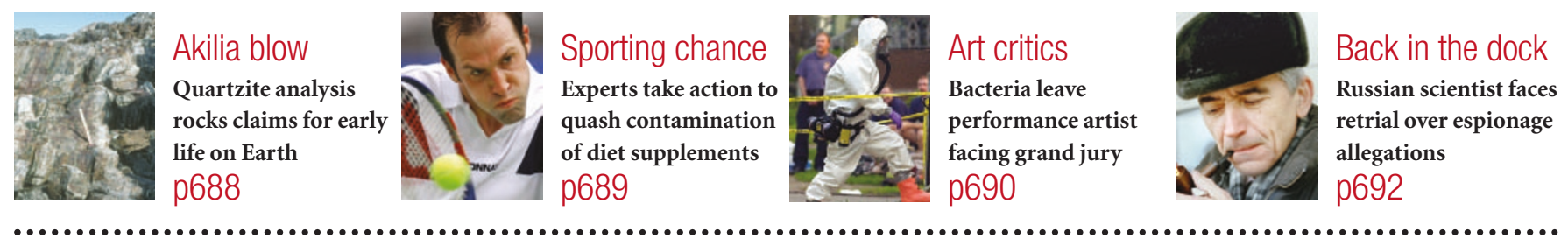

\title{
Scientists cry foul as Elsevier axes paper on cancer mortality
}

Meredith Wadman, Washington

Contributors to a medical journal are refusing to publish in an upcoming issue on health in the semiconductor industry unless a controversial paper, axed by the publisher, is included.

The paper in question discusses rates of cancer mortality among former employees of computer manufacturer IBM. But Elsevier, the publisher of Clinics in Occupational and Environmental Medicine, announced last week that it would not publish the paper on the grounds that it was not a review article.

"It was determined that it was original research and the format of it wasn't appropriate for Clinics, which is a review journal," says Eric Merkel-Sobotta, a spokesman for the Amsterdam-based publisher.

But the guest editor of the upcoming issue, and many of its contributing authors, say that this is not the real reason for the paper's removal. They allege, instead, that Elsevier is bowing to pressure from IBM not to publish it. Elsevier denies that pressure from IBM had any bearing on its decision.

The paper presents an analysis of mortality records for 32,000 IBM employees over 32 years. These records were originally submitted to lawyers by IBM last year during a court case in Santa Clara County, California, in which the company was sued by two former employees who alleged that their health had been affected by their jobs. Richard Clapp, an epidemiologist at Boston University, Massachusetts, and one of the paper's two authors, was an expert witness for the complainants and analysed the data supplied by IBM on their behalf.

Nature has obtained a copy of the study, which Clapp co-authored with Rebecca Johnson, an epidemiologist who runs Epicenter, a consulting firm in Circle Pines, Minnesota. It reports significantly more deaths from several kinds of cancer in IBM employees than would be expected from data for the general population, and higher-still cancer

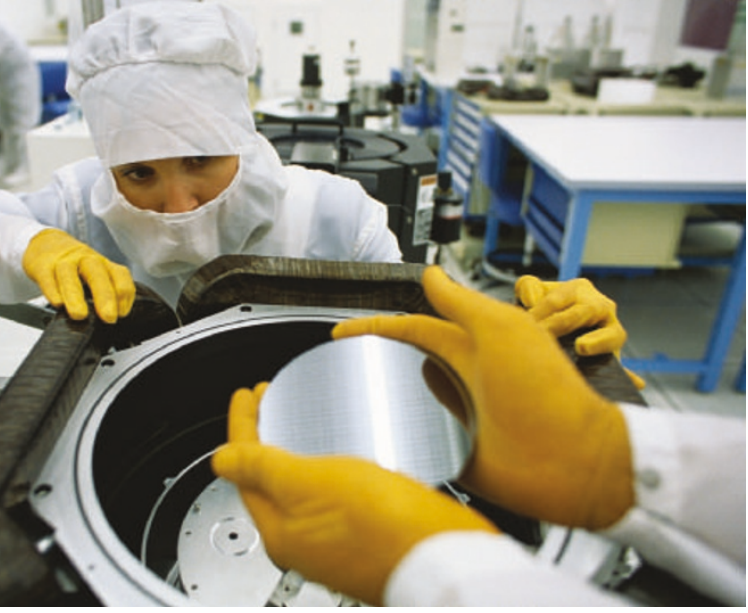

death-rates for workers who spent at least a month at IBM chip-manufacturing plants.

"If the material is worthy, and the editor is satisfied the piece meets the journal's scientific standards, the publisher's interference smacks of censorship," says Clinics contributor Daniel Teitelbaum, a medical toxicologist at the Colorado School of Mines in Golden. "This is precisely the problem presented by Elsevier's refusal to publish the Clapp-Johnson paper."

\section{Standing firm}

Joseph LaDou, the guest editor of the Clin$i c s$ issue on the electronics and semiconductor industries, which is scheduled for publication in November, adds: "We are standing together with Clapp and Johnson. We will publish when they publish, wherever that may be." LaDou, who is director of the International Center for Occupational Medicine at the University of California, San Francisco, says that the paper had passed muster with four peer-reviewers drawn from among the issue's contributors.

He adds that on 6 June, the day that Elsevier informed him that the Clapp-Johnson paper would not be published, he called on the journal's contributors to consider withholding their pieces from publication. By 9 June, seven of the nine contributors had agreed to withhold their papers. As of 14
June, LaDou had not heard back from the other two. But Elsevier remains unmoved. "Boycotts are neither constructive nor effective," says Merkel-Sobotta.

Lawyers for IBM argue that the data used in the paper fall under a protective court order that prohibits their use for anything other than the Santa Clara lawsuit. "Dr Clapp cannot arrogate to himself judgements about what court orders have to be obeyed and what ones don't," says Robert Weber, a Cleveland-based attorney who represented IBM in the lawsuit.

LaDou had also agreed to be an expert witness in the lawsuit, although the plaintiffs' lawyers did not call on him. The suit was decided in favour of IBM by a jury in February. The judge did not allow the data, and the conclusions drawn from them by Clapp and Johnson, to be presented to the jury, writing that they do "not and cannot demonstrate that there is any connection between the results of the study and exposure to chemicals at IBM". Some 200 similar lawsuits against the company are still in process.

But Clapp says that the broad pattern demonstrated by the huge database is important. He referred questions on the court order to his attorney, Indira Talwani. She says that IBM failed to mark as 'confidential' the deposition containing the study and Clapp's lengthy discussion of it with IBM lawyers. As a result, the plaintiffs' lawyers sent it to The New York Times, which published details of it last September. In addition, she says, any citizen may access the deposition containing the study at the Santa Clara County courthouse. "The stuff is in the public domain now, because IBM didn't take the right steps," she says.

Clapp initially withdrew the paper from Clinics in March, after being warned by an IBM lawyer not to publish it, Talwani says. But he resubmitted it after taking legal advice and concluding that IBM no longer had the legal right to kept the study private. 